\title{
The FMI emission inventory and source-receptor calculations across Finland's eastern border
}

\author{
Marke Hongisto \\ Finnish Meteorological Institute, \\ Erik Palmenin Aukio 1, \\ P.O. Box 503, \\ FI-00101, Helsinki, Finland \\ Email: marke.hongisto@fmi.fi
}

\begin{abstract}
The source-receptor calculations of European monitoring and evaluation program (EMEP) between Finland and Russia have been discussed in the Finnish public media in autumn 2013 after the Russian environmental organisation Green Patrol accused Western countries of polluting the Kola Peninsula. The air pollution fluxes between Russia and Nordic countries calculated with the EMEP western centre are based on emission data, which in North-Western Russia are significantly lower than in other European emission inventories. In this paper, North-Western Russian air emissions and the pollution fluxes between Finland, Russia and the Baltic Sea are discussed.
\end{abstract}

Keywords: emission inventory; deposition; sulphur; nitrogen; source-receptor matrixes; Finland; North-Western Russia; Murmansk Oblast; Karelia; Leningrad Oblast; St. Petersburg.

Reference to this paper should be made as follows: Hongisto, M. (2015) 'The FMI emission inventory and source-receptor calculations across Finland's eastern border', Int. J. Environment and Pollution, Vol. 58, Nos. 1/2, pp.15-26.

Biographical notes: Marke Hongisto received her Dr (Tech) in 2003 from the Helsinki University of Technology Department of Technical Physics, and has experience working as a Teacher and Scientist in the fields of nuclear engineering, applied mathematics, system theory and nonlinear optimisation. At the Finnish Meteorological Institute, she has constructed a set of Eulerian chemistry-transport models studying long-range transport of pollutants in Europe, Finland and the Baltic Sea area. For this task, she has collected and maintained emission inventories and meteorological database.

This paper is a revised and expanded version of a paper entitled 'The FMI emission inventory and source-receptor calculations at the Finnish Eastern border' presented at the 16th International Conference on Harmonisation within Atmospheric Dispersion Modelling for Regulatory Purposes, Varna, Bulgaria, 8-11 September 2014. The paper is submitted for a special issue with Ekaterina Batchvarova as guest editor. 


\section{Introduction}

The international convention on long-range transboundary air pollution was signed in Geneva, 1979. In accordance with the treaty, air pollutant exchange between European countries has been followed by annual model simulations at European monitoring and evaluation program (EMEP) eastern and western centres. One of the main uncertainties of this work is the inaccuracy of air pollutant emission data. Although the earliest estimates of gridded emissions in Europe extend back to the 1880s (Mylona, 1996; Aardenne et al., 2001), there remains high uncertainty in the current air emissions. The $\mathrm{SO}_{2}$ emission sum over the Murmansk region (Murmansk Oblast, MO) in North-Western (NW) Russia in 2007 was $21.2 \mathrm{kt} \mathrm{SO}_{2}$ in the EMEP inventory, but $289.3 \mathrm{kt} \mathrm{SO}_{2}$ in the MACC (TNO, 2007) inventory. The MACC oxidised nitrogen $\left(\mathrm{NO}_{\mathrm{x}}\right)$ emissions $\left(19 \mathrm{kt} \mathrm{NO}_{2}\right)$ were lower than the corresponding EMEP emissions $\left(35 \mathrm{kt} \mathrm{NO}_{2}\right)$.

The $\mathrm{MO}$ annual $\mathrm{SO}_{2}$ emissions in the EMEP database (DB), being 450-480 kt $\mathrm{SO}_{2}$ in 2000-2003, were suddenly cut to $32.4 \mathrm{kt} \mathrm{SO}_{2}$ in 2004 and step by step to $18.7 \mathrm{kt}$ in 2010 . Later also the historical emissions were reduced. There have been unexpected changes in the Russian $\mathrm{NO}_{\mathrm{x}}$ emissions in Leningrad Oblast (LO) and St. Petersburg between the EMEP inventories of two adjacent years. Owing to these uncertainties, the Finnish Meteorological Institute (FMI) has maintained an emission DB for MO, Karelia and LO. In this paper this inventory, a review of the largest NW Russian air pollution sources and pollution fluxes across the Finnish eastern border are presented.

\section{Materials and methods}

\subsection{Model}

The contribution of the MO, Karelia, LO and Finnish sulphur and nitrogen emissions to Finland, MO and Baltic Sea (BS) deposition was calculated with the FMI regional grid model Hilatar (Hongisto, 2003). It uses the FMI operative high resolution limited area model weather predictions. The model has a $0.068^{\circ}$ horizontal resolution and 21 vertical levels. It has off-line nesting with the European Hilatar of $0.15^{\circ}$ resolution. The chemistry module includes compounds of oxidised and reduced nitrogen (N) and sulphur (S).

The model uses MACC (TNO, 2007) European emissions completed with the EMEP WebDab inventory for the missing sectors, the FMI NW Russian inventory, the BS ship emissions with $450 \mathrm{~s}$ time interval (Jalkanen et al., 2012) and Finnish national stack and areal emissions compiled by the Finnish Environmental Institute (FEI). The Finnish total sulphur emissions decreased from $263 \mathrm{kt}$ to $47 \mathrm{kt} \mathrm{SO}_{2}$, the $\mathrm{NO}_{\mathrm{x}}$ emissions from 285 to $145 \mathrm{kt} \mathrm{NO}_{2}$ and the $\mathrm{NH}_{3}$ emissions from 39 to $37 \mathrm{kt}$ in 1990-2013. The traffic emissions decreased from 127 to $38 \mathrm{kt} \mathrm{NO}$ and from $9 \mathrm{kt} \mathrm{SO}$ to $74 \mathrm{t} \mathrm{SO}_{2}$ in 1980-2013 although the traffic volume increased from $28 \mathrm{G}$ to $57 \mathrm{G}$ vehicle-km during the same period (FEI, 2015; VTT, 2015). The Finnish stack emission inventory is based on annually updated environmental permit register data (Compliance Monitoring Data System at the Centres for Economic Development, Transport and the Environment; FEI, 2015). For 2012 the stack register contains 838/1075/14 individual sources for sulphur, $\mathrm{NO}_{\mathrm{x}}$ and ammonia, respectively. The dispersed emissions are based on Finnish regional emission scenario model (Karvosenoja, 2008) estimates, updated by annual emission sum changes. 


\subsection{The Finnish emissions inventory for NW Russia}

FMI has maintained an emission inventory for NW Russia since the 1990s (Häkkinen et al., 1995; Hongisto, 2003). Emissions of LO, Saint Petersburg and Karelia were estimated with the SRI Atmosphera researchers for the base year 1993. The MO emissions were based on the MO (1994) information on emissions for administrative districts, industry and individual sources. The traffic emissions were estimated for LO and Karelia by the Russian traffic model of the State Technical Research Centre (Mäkelä and Salo, 1993). Problems in updating the Russian emissions include the variation in production due to economic chaos and privatisation after the collapse of the USSR, the old technology for which the western specific emission factors cannot be directly used, the practice of the Russian statistical centre to report only the sum of all emission into atmosphere and the convention of some companies to leave the air emissions unreported. Thus a review on emissions in NW Russia is given.

\subsection{Murmansk region}

The MO economy includes mining and related ore/metal processing, phosphate fertiliser production, military, shipping and polar marine technology related industry, construction, forest, fish, food and energy industry and agriculture. After the collapse of the Soviet Union in 1991, the production of MO industry fell to $85 \%$ of the reference value, varying between $90 \%-120 \%$ in 1995-2013. The mining and energy industry sectors recovered faster, their production index being around 110\% already in 1995 (Knoema, 2014).

The population of the MO decreased from 1.19 M (1990) to $0.78 \mathrm{M}$ in 2012. The urban population share increased to $92.75 \%$ (Knoema, 2014). The share of the armed forces and police of labour decreased from 17\% to 10\% between 1992 and 1997, while the heavy industry share increased from 5\% to $6 \%$ (Hansen and Tønnessen, 1998). There are seven naval bases of the Russian Northern Fleet (the main base in Severomorsk), six shipyards and four spent nuclear fuel storage sites in Kola Peninsula. The administrative centre of MO is Murmansk with 307,257 inhabitants in 2012.

The total sum of air emissions in MO, based on Russian Federal Service of State Statistics (Knoema, 2014), decreased from a maximum of $617 \mathrm{kt}$ in 1992 to $373 \mathrm{kt}$ in 2000 , and by $28 \%$ to $269.8 \mathrm{kt}$ in 2013 . The $\mathrm{SO}_{2} / \mathrm{NO}_{\mathrm{x}} /$ dust emissions from fossil fuel combustion decreased from $96.3 / 12.5 / 15.2 \mathrm{kt}$ in 2001 to $65.8 / 10.6 / 4.3 \mathrm{kt}$ in 2012 . According to Tikkanen (1995) and the EMEP DB before 2004 the MO sulphur emissions exceeded $700 \mathrm{kt} \mathrm{SO}_{2}$ in 1984, decreased to $464 \mathrm{kt}$ in 1997 and stayed on the same level in the beginning of the 2000s. According to Bambulyak et al. (2013) the MO total $\mathrm{SO}_{2}$ emissions were $240 \mathrm{kt} \mathrm{SO}$, and the total industrial emissions $320 \mathrm{kt}$ in 2012. The largest air pollution emitters are the Kola MMC Ni and Co smelters in Nikel, Zapolyarny and Monchegorsk. The Kola MMC smelters total emissions were 143.5/154.8/148.6/165.4 kt in 2008/2010/2012/2014, of which $\mathrm{SO}_{2} 136 . / 150.2 \mathrm{kt}$ in 2012/2014 (Norilsk Nikel, 2015).

Kozlov et al. (2009) reports the main emissions of selected enterprises over their whole operating time up to the year 2005. After 1978 the Kozlov emissions of PechengaNikel (Nikel and Zapolyarny) and Monchegorsk SeveroNikel plants equal the AMAP and in 2003 and 2011 the NEFCO/AMAP emissions (Bambulyak et al., 2013) and since 1990 the Norilsk Nikel (2015) values. The PechengaNikel $\mathrm{SO}_{2}$ emissions decreased from $396 \mathrm{kt}$ in $1973 \mathrm{kt}$ to $100.7 \mathrm{kt}$ in 2011. The Monchegorsk smelter $\mathrm{SO}_{2}$ 
emissions varied between 100 and $200 \mathrm{kt}$ in the 1960s, peaked at $307 \mathrm{kt}$ in 1976 decreasing to $33.5 \mathrm{kt}$ in 2009. The $\mathrm{NO}_{2}$ emissions in 2005 (2,000) were 10 (200), $300(200)$ and $700(1,500) \mathrm{t} \mathrm{NO}_{2}$ for Nikel, Zapoljarnyi and Monchegorsk, respectively (Kozlov et al., 2009).

Other high polluters in MO are the heating power plants (HPP) of Murmansk and Apatity, the Kandalaksha aluminium (Al) smelter, Apatit JSC, Kovdor ore mining and processing enterprise, Kovdorsluda PC, the phosphorus company of Agron Group in Kirovsk (NWPC, 2014), the Olkon PC Severstal OAO and the Olenegorsk mining and concentration works. JSC Apatit extracts and processes apatite and nepheline ores in Khibinä mountain area at four mines (PhosAgro, 2014) with air emission of 7.0/1.8/3.2 kt in 2003 and 6.0/0.6/2.3 kt SO $2 / \mathrm{CO} / \mathrm{NO}_{2}$ in 2011 (Bambulyak et al., 2013). Kozlov et al. (2009) reports slightly higher $\mathrm{SO}_{2}$ and $\mathrm{NO}_{2}$ emissions but only $0.2 \mathrm{kt} \mathrm{CO}$ in 2003.

The NW Russian energy production industry is described in Efimov (2007). The TGC-1 monthly electricity and heat productions, fuel use and operational efficiencies for the years 2009-2013 are presented in TGC-1 (2014). A list of Russian power plants with $\mathrm{CO}_{2}$ emission, power and coordinates for majority of the plants can be found on the Carbon monitoring action DB (CARMA, 2014).

The coal-fuelled Apatitskaya combined heat and power plant (CHPP), belonging to the Kolskiy Branch of TGC-1, has $266 \mathrm{MW}_{\mathrm{e}}$ installed capacity and $590 \mathrm{Gcal} \mathrm{h}^{-1}$ heat production. In 2011 TGC-1 JSC and Apatit JSC established the Hibiny Heat Company for the CHPP renovation and for heating the city Kirovsk. The emissions were 2.4-2.8 kt $\mathrm{NO}_{2}$ and 9.2-12.2 kt $\mathrm{SO}_{2}$ in 2007-2011 (Bambulyak et al., 2013). The Murmanskaya CHPP uses heavy oil (TGC-1, 2014). In MO there are also two nuclear units in Poljarnoi Zori, 20 hydropower plants in four rivers and local boilers and heat sources belonging to the process industry.

The Kovdorsky GOK total atmospheric emissions per tonne of production have been $1.15 \mathrm{~kg} \mathrm{t}^{-1}$ in $2009,1.04 \mathrm{~kg} \mathrm{t}^{-1}$ in 2012-2013 and the production volumes 5,700 kt iron ore, 2,700 kt Apatite and $10 \mathrm{kt}$ baddeleyite (Eurochem, 2014). In 2006 the Kovdorsky GOK emissions in air were $10 \mathrm{kt}$, of which $30 \%$ was $\mathrm{SO}_{2}$ and $19 \% \mathrm{NO}_{2}$ (Eurochem Annual Report, 2006). The main products of the Kovdorsluda enterprise in Kovdor have been alumosilicates, mica of different kinds and grades. The Olenegorsk Iron Ore Complex (OAO Olcon, Severstal) strip-mines at four deposits. Strip-mining is combined with deep mining at the Olenegorsk mine since 2005. In 2008 ans 2012 the production was $4.8 \mathrm{M}$ tons of iron ore (Severstal, 2014).

At the Kandalaksha Al plant with production capacity $76 \mathrm{kt} \mathrm{Al}$ in 2010 a new gas-cleaning system was installed in 2005, and the plant was further modernised in 2011-2013 (RusAl, 2014). The total emissions from industrial enterprises in Kandalaksha were $6 \mathrm{kt} \mathrm{SO}_{2}, 6.7 \mathrm{kt} \mathrm{CO}, 500 \mathrm{t} \mathrm{NO}_{\mathrm{x}}$ and $3.8 \mathrm{kt}$ dust in 2006 (Kozlov et al., 2009).

The agricultural production, fishing industry, port activity and transport volumes for the years 2007-2012 in MO, LO and Karelia are quantified in Knoema (2014) but, without knowledge of areal distribution. 16\% of the overall Russian fishing catch is produced in MO. The fishing sector consists of a fisheries fleet and the onshore complex including port facilities, onshore fish-processing enterprises and shipyard companies. The Murmansk port, capable of receiving vessels of $300 \mathrm{kt}$ deadweight all the year round, provides vessel servicing, fuel loading and petroleum storage, moorings, loading and unloading facilities as well as production storage and selling facilities (MO, 2014). 


\section{Republic of Karelia}

The total industrial $\mathrm{SO}_{2} / \mathrm{NO}_{\mathrm{x}} /$ dust/CO emissions of the Republic of Karelia were $77 / 6 / 28 / 23 \mathrm{kt}$ in 2002 and 56/7/18/13 kt in 2011 and the total traffic emissions 53/74 kt in 2002/2011 (Bambulyak et al., 2013), while Knoema (2014) reports 137/96/119 kt total emissions in 2002/2011/2013 from stationary and mobile sources. The fossil fuel combustion emissions were 16.4/4.8/4.1/8.9 kt, respectively. 56.8\% of static emissions were from mineral extraction, $17.6 \%$ from pulp and paper industry, $12.8 \%$ from energy production and distribution and water and 7.9\% from metal industry in 2013 (Karelia, 2014). The enterprises producing main industrial air emissions are Karelsky Okatysh JSC, NAZ-SUAL branch of SUAL JSC (Nadvoitsy Al factory) and pulp and paper enterprises Kondopoga JSC, Segezhsky PPM JSC and CZ Pitkyaranta JSC.

The largest emitter of the administrative centre Pedrozavodsk is the machine-building company Petrozavodskmash JSC of Rosatom Atomenergomash. The change of the fuel to natural gas reduced its HPP emissions from 1,563 t SO 2 in 2003 to $886 \mathrm{t}$ in 2007 and further to $40 \mathrm{t}$ in 2011. The emissions of the Olonetsk and Suoyarskaya paperboard mill HPP's were 1,358 and 2,163 $\mathrm{t} \mathrm{SO}_{2}$ in 2003, 1,476 and 1,493 $\mathrm{t} \mathrm{SO}_{2}$ in 2011. With use of local biofuel the shares of the coal use decreased from $15.2 \%$ to $10.5 \%$, and of heavy oil use from $27.2 \%$ to $19.7 \%$ in the period 2005-2010 (Bambulyak, 2013).

The Karelsky Okatysh in Kostamuksha produced 22.3 Mt of ore and 7.6 Mt iron pellets in 2004. The industrial emissions were $6.1 \mathrm{kt}$ dust, $36.5 \mathrm{kt} \mathrm{SO} \mathrm{S}_{2}, 1.4 \mathrm{kt} \mathrm{CO}$ and $2.1 \mathrm{kt} \mathrm{NO}_{2}$ in 2005. From the dust analysis estimated emissions of heavy metals in 2000 were $350 \mathrm{t} \mathrm{Fe}, 27 \mathrm{tn} \mathrm{Zn}$ and $0.6 \mathrm{t} \mathrm{Cu}$ (Kozlov, 2009). The factory has three separate production lines, each having its own stack for flue gases $\left(222 \mathrm{~m}^{3} \mathrm{n} \mathrm{s}^{-1}\right.$ with $5 \mathrm{~g} \mathrm{~m}^{-3} \mathrm{n} \mathrm{SO}_{2}$ in 2006). The maximum annual emissions are $96 \mathrm{kt} \mathrm{SO}_{2}$ (with $92 \%$ operation time) but the reported emissions have been $30-36.5 \mathrm{kt} \mathrm{SO}_{2}$ in the 2000s. The flue gas desulphurisation system of one stack was tested in 2004, but it was never taken into continuous operation.

The use of natural gas at the Kondopoga JSC pulp and paper mill (PPM) with production of $260 \mathrm{kt}$ newsprint in 2012, reduced the air emissions of the HPP from $18.6 \mathrm{kt} \mathrm{SO}_{2}$ and $1.6 \mathrm{kt} \mathrm{NO}_{2}$ in 2003 to $2.4 \mathrm{kt} \mathrm{SO}_{2}$ and $1.5 \mathrm{kt} \mathrm{NO}_{2}$ in 2011 (Bambulyak, 2013).

The Segezhsky PPM JSC of Investlesprom producing $500 \mathrm{M}$ paper sacks from $400 \mathrm{kt}$ pulp provides heat and hot water supply to the city of Segezha with 30,000 inhabitants. In the 2000s the mill has been modernised. The production is scheduled to increase with investment support of AFK Systema (Karelia, 2014; METLA, 2014; Segezha, 2014).

CZ Pitkyaranta JSC with carton and around $80 \mathrm{kt}$ annual pulp production was declared bankrupt and sold in 2013 to CTS Invest but the production has been kept on the 2012 level in 2013 (METLA, 2014). The Suoyarvi paperboard and carton mill has been sold by Petrozavodskmas in 2004 to Kondopoga JSC. The modernised mill with four-fold production was sold in 2010 to Avtomatisatsija (Idän metsätieto, 2010). There are also several plywood, chipboard and sawmills, wood pellet and bricked producers with changing capacities, production and ownerships in Karelia (Gerasimov et al., 2009).

The emissions of the Nadvoitsy Al plant (capacity $81 \mathrm{kt} \mathrm{Al}$ ) grew from $6.8 \mathrm{kt}$ in 2003 to $8.9 \mathrm{kt}$ in 2011 although it was modernised and the boiler fuel was changed to natural gas (Bambulyak et al., 2013). Kozlov et al. (2009) reported Nadvoisy emissions were 
3(3) kt dust, 1.2(1.2) $\mathrm{kt} \mathrm{SO}_{2}, 2.7(2.4) \mathrm{kt} \mathrm{CO}, 70(70) \mathrm{t} \mathrm{NO}_{\mathrm{x}}$ and 318(313) t $\mathrm{HF}$ in 2003 (2005).

Many of the RUSAL Al smelters are old and a modernisation program has been ongoing. Production of alumina hydrate at Boxitogorsk Refinery was stopped in 2011, but the refinery started to purchase raw material from the nearby Pikalevo Alumina Plant for its corundum production. The Volkhov smelter in LO was closed in August 2013, and three of the four potrooms of the Nadvoitsy smelter in September 2012, the latter two with remark: no potential re-start; main equipment is being dismantled (RusAl, 2014).

\section{LO and St. Petersburg}

The variation of total annual emissions in LO (471 kt in 1992, $244.7 \mathrm{kt}$ in 2013 from static and mobile sources) as well as population, industry and agriculture volumes are reported by Knoema (2014). The population was around $1.67 \mathrm{M}$ in the $1990 \mathrm{~s}, 1.74 \mathrm{M}$ in 2012. The urban population share decreased to $65.3 \%$ in 2012 . The annual industrial production volumes varied since 1992 between $85 \%-126 \%$ (being $93 \%$ in 2013), the mining volumes by $57 \%-132 \%$, manufacturing by $86 \%-125 \%$ and energy use by $88 \%-112 \%$ of the reference value. The LO air emissions from fossil fuel use were $6.31 \mathrm{kt}$ $\mathrm{SO}_{2}, 12.78 \mathrm{kt} \mathrm{NO}$ and $3.64 \mathrm{kt}$ dust in 2012 according to Knoema (2014).

The St. Petersburg population which decreased after 1990 by 0.34 M people to 4.66 $M$ in 2003, exceeded again $5 \mathrm{M}$ in 2013. The official total industrial and mobile air pollutant emissions were $57.5 \mathrm{kt}$ in 2001 and $68.9 \mathrm{kt}$ in 2012, of which the energy sector accounted $5.13 \mathrm{kt} \mathrm{SO}_{2}, 25.8 \mathrm{kt} \mathrm{NO}_{2}, 0.92 \mathrm{kt}$ dust, $16.24 \mathrm{kt} \mathrm{CO}$ and $50 \mathrm{t} \mathrm{VOC} \mathrm{(Knoema,}$ 2014). The city officials, when giving presentations during visits to FMI, have reported higher, 270-342 kt total emissions for 2004-2008 (49.9 $\mathrm{kt} \mathrm{NO}_{2}, 8.6 \mathrm{kt} \mathrm{SO}_{2}$ in 2008).

Leningrad nuclear power plant produces almost $60 \%$ of the electricity for the LO region. The largest CHPP is the Kirishi main regional power plant with $800 \mathrm{MW}_{\mathrm{e}}$ electric capacity. The main type of fuel used at TGC-1 Nevsky Branch power stations is natural and dry stripped gas with oil and coal as reserve fuel. The CHPP's have been frequently modernised and new facilities have been launched in the 2000s.

The industrial enterprises of the LO produce a wide assortment of industrial and technological products including petrol, diesel fuel, mineral fertilisers, aluminum, industrial wood, cellulose, paper, cardboard, machines, devices, and construction materials and consumer goods. $23 \%$ of the working age population of the region is employed in small business (including registered farms - 6,032 units) (LO, 2014).

The Kirishinefteorgsintez (Kinef, subsidiary of Surgutneftegaz) plant in Kirishi is one of the largest oil refineries in Russia with production of 18.9 (19.5) Mt in 2013 (2009). Surgutneftegaz (2014) reports only the sum of the emissions of the whole company in 2007-2013, the refinery emissions have to be calculated from the production figures. There is also oil shale mining and processing industry in Slantsy and chemical, glass, and food industries in Kingisepp which were in the soviet time heavy polluted sites.

In the forest sector there are Syasky (2014) PPM, OAO Svetogorsk PPM (International Paper, Sveto, 2014a) with nearby Svetogorsk Tissue of Svenska Cellusosa Aktiebolag (Sveto, 2014b), Vyborskaya Cellulose with a new pellet factory of $1 \mathrm{M} \mathrm{t} \mathrm{yr}^{-1}$ production and the corrugated board plant of Ilim pulp, OAO St. Petersburg cardboard and printing mill. There are also large machine manufacturers (Teknstroymash, forest sector). The production of forest industry sectors sawn wood, plywood, particle board 
and fibreboard, pulp, paper and paperboard in 1993-2008, the biggest companies, utilisation of wood and machine manufacturers in the forest sector are reported in Gerasimov et al. (2009).

The Pikalevo and the Olhava Al-smelters are also situated in LO. In 2005 the emissions of the Volkhov Al plant (started in the 1930s) were 2,000 t dust, 1,000 $\mathrm{SSO}_{2}$, $300 \mathrm{t} \mathrm{NO}_{2}$ and $24 \mathrm{t} \mathrm{HF}$. In Kamenogorsk there are chemical, building material and food industries.

The total sums of emissions used in the simulations for 2011 were 240.5, 63.4 and $51.6 \mathrm{kt} \mathrm{SO}_{2}$ and 25.6, 18.7 and $92.9 \mathrm{t} \mathrm{NO}_{2}$ for $\mathrm{MO}$, Karelia and LO+St.Petersburg, respectively. The St Petersburg emissions followed the city authority estimates. The emissions were split among the Si-classes 1-10. A minor share of the total emissions were divided over the whole respective land areas evenly, know point sources presented partly in Table 1 were allocated to the respective grids, the traffic emissions (sectors S7 and S8) were distributed along the main roads and city traffic and the rest emissions were divided between the main urban areas (30 centres in Karelia, 79 in LO, 33 in MO) with weighting by population number.

Table 1 The main point source locations and emission sums in Karelia, LO and Kola Peninsula use in the simulations

\begin{tabular}{|c|c|c|c|c|}
\hline \multicolumn{5}{|c|}{ Karelia main point sources (total 34) } \\
\hline$t \mathrm{SO}_{2}$ and $\mathrm{NO}_{2}$ & & & $\mathrm{SO} 2$ & NO2 \\
\hline Kostamus & 64.60 & 30.07 & 40,000 & 2,000 \\
\hline Vojatyi.Nadvoitsa & 63.90 & 34.08 & 1,500 & 100 \\
\hline Nadvoitsy & 63.92 & 34.25 & 300 & 50 \\
\hline Segezha & 63.75 & 34.30 & 2,300 & 650 \\
\hline Pitkaranta & 61.57 & 31.47 & 1,500 & 500 \\
\hline Sortavala & 61.73 & 30.68 & 500 & 150 \\
\hline Petroskoi & 61.78 & 34.05 & 1,450 & 4,900 \\
\hline Kontupohja & 62.18 & 34.12 & 1,700 & 2,500 \\
\hline Karhumaki & 62.92 & 34.45 & 200 & 50 \\
\hline Suojarvi & 62.00 & 32.40 & 1,000 & 200 \\
\hline Sorakka & 64.50 & 34.75 & 700 & 100 \\
\hline Vienan & 64.97 & 34.55 & 800 & 170 \\
\hline \multicolumn{5}{|c|}{ Leningrad oblast main point sources (total 15) } \\
\hline$t \mathrm{SO}_{2}$ and $\mathrm{NO}_{2}$ & Lat & Lon & SO2 & NO2 \\
\hline Kirishi & 59.47 & 32.03 & 15,100 & 7,110 \\
\hline Sjastroi & 60.17 & 32.57 & 1,000 & 500 \\
\hline Kingisepp & 59.38 & 28.58 & 2,000 & 600 \\
\hline Olhava & 59.90 & 32.37 & 200 & 400 \\
\hline Svetogorsk & 61.12 & 28.87 & 150 & 1,280 \\
\hline Viipuri. & 60.72 & 28.75 & 933 & 500 \\
\hline Kamenogorsk & 60.97 & 29.07 & 200 & 100 \\
\hline Lesogorsk & 60.97 & 28.93 & 200 & 150 \\
\hline Sovetski,Johannes & 60.55 & 28.72 & 700 & 700 \\
\hline Pikalevo & 59.53 & 34.17 & 200 & 500 \\
\hline
\end{tabular}


Table 1 The main point source locations and emission sums in Karelia, LO and Kola Peninsula use in the simulations (continued)

\begin{tabular}{lcccc}
\hline \multicolumn{4}{c}{ Kola Peninsula main point sources } & (total 41) \\
\hline$t \mathrm{SO}_{2}$ and $\mathrm{NO}_{2}$ & Lat & Lon & SO2 & NO2 \\
\hline Murmansk & 68.90 & 33.10 & 22,670 & 643 \\
Kantalahti & 67.17 & 32.40 & 4,475 & 274 \\
Olenogorsk & 68.14 & 33.25 & 3,690 & 296 \\
Poljarnyi & 69.20 & 33.45 & 4,886 & 580 \\
Severomorsk & 69.07 & 33.35 & 5,256 & 377 \\
Kola district & 68.87 & 33.00 & 1,298 & 87 \\
Kovdor district & 67.55 & 30.40 & 4,215 & 131 \\
Apatit & 67.63 & 33.40 & 15,270 & 3,838 \\
Kirovsk & 67.67 & 33.75 & 2,660 & 39 \\
Lovozersky district & 68.02 & 35.10 & 1,595 & 80 \\
Terin district & 66.70 & 34.30 & 359 & 18 \\
Montshegorsk & 67.90 & 32.85 & 33,500 & 1,570 \\
Zapoljarnyi & 69.40 & 30.65 & 52,500 & 500 \\
Petshanganikel & 69.42 & 30.25 & 50,670 & 235 \\
\hline Sum & & & 203,044 & 8,668 \\
\hline
\end{tabular}

\section{Results}

The depositions of sulphur and nitrogen originated from MO, Karelia and LO (MoKaLO) emissions and separately from MO and from Finnish emissions in 2011 are presented in Figure 1, the monthly variation of MoKaLO deposition in Figure 2 and the deposition sums to the target areas in Table 2. Only grids where the target area share is $>99 \%$ were included in the budgets because of coastal gradients, thus the target areas were 319,372 , 496,000 and 135,000 $\mathrm{km}^{2}$ for Finland, BS, MoLaLO and MO, respectively.

The MoKaLO deposition share exceeded $50 \%$ along the whole Finnish-Russian border being higher, over $80 \%$, near the Kostamus and Kola Peninsula sources. Kozlov et al. (2009) reports $2.1 \mathrm{~g}(\mathrm{~S}) \mathrm{m}^{-2}$ deposition in the mid-1990s near Kostamus and Monchegorsk, now the deposition exceeded $0.5 \mathrm{~g}(\mathrm{~S}) \mathrm{m}^{-2}$. The MoKaLO emissions contributed by $15 \mathrm{kt} \mathrm{S}$ and $4.6 \mathrm{kt} \mathrm{N}$ to the Finnish sulphur and $\mathrm{NO}_{\mathrm{x}}$ depositions while the contribution to the BS deposition was $2.6 \mathrm{kt} \mathrm{S}$ and $1.6 \mathrm{kt} \mathrm{N}$. The MO contribution to Finland was $6.3 \mathrm{kt} \mathrm{S}$ and $1.6 \mathrm{kt} \mathrm{N}$ and to BS only $0.3 \mathrm{kt}$ both $\mathrm{N}$ and $\mathrm{S}$. The BS ship-emission ( $95 \mathrm{kt} \mathrm{SO}_{2}$ in 2011) originated sulphur deposition contributed by $15 \mathrm{kt} \mathrm{S}$ to the $\mathrm{BS}$ deposition. The $\mathrm{MO} \mathrm{NO}_{\mathrm{x}}$ deposition originated from Finnish emissions was $5.7 \mathrm{kt}$ $\mathrm{N}$; it decreased from $7 \%-10 \%$ at the Finnish border to below $2 \%$ of the total $\mathrm{NO}_{\mathrm{x}}$ deposition in the eastern parts of the Kola Peninsula. 
Figure 1 Sulphur and nitrogen depositions originated from MO, Karelia and LO emissions, from $\mathrm{MO}$ and from Finnish emissions (see online version for colours)
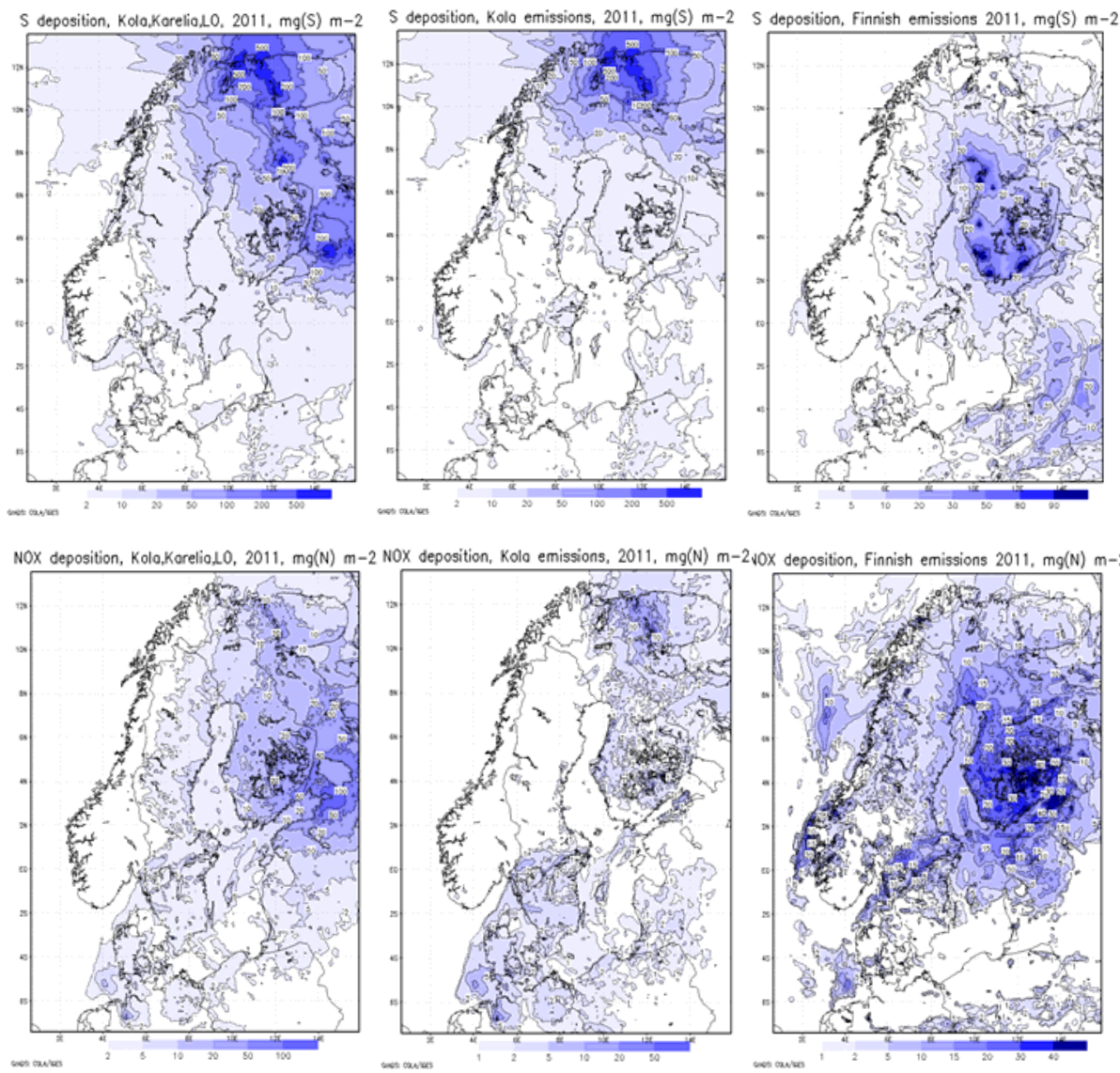

Figure 2 Monthly variation of deposition from Kola, Karelia and LO emissions to the BS, Finland and Kola Peninsula, \% of annual value 2011 (see online version for colours)

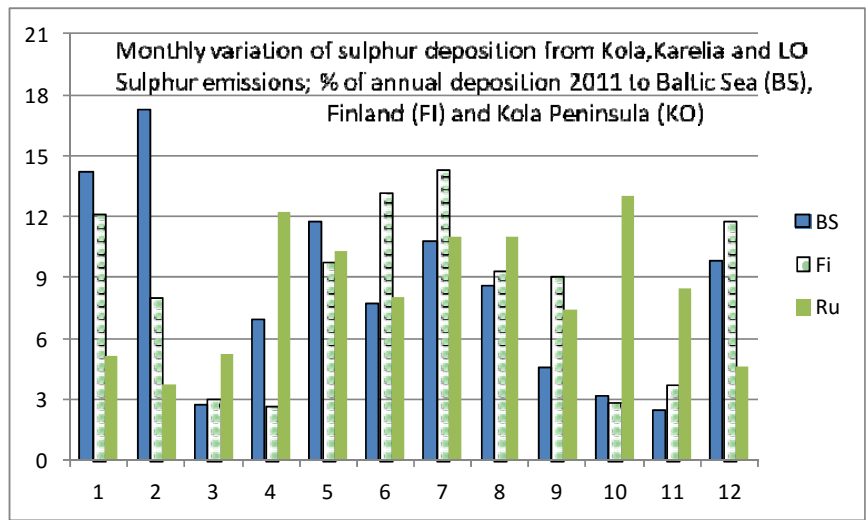


Table 2 Deposition of oxidised nitrogen (NOx) and sulphur (SOx) from MO, Karelia and Leningrad Oblast (KoKaLO), Finnish and MO emissions to the BS, Finland and MO in 2011

\begin{tabular}{llccccccc}
\hline \multirow{2}{*}{2011} & & \multicolumn{3}{c}{ SOx deposition, $t S$} & & \multicolumn{3}{c}{ NOx deposition, $t N$} \\
\cline { 3 - 4 } \cline { 8 - 9 } & & Tot & Wet & Dry & & Tot & Wet & Dry \\
\hline From MoKaLO & To Baltic Sea & 2,644 & 1,658 & 984 & & 1,580 & 962 & 616 \\
From MoKaLO & To Finland & 15,061 & 9,715 & 5,346 & & 4,559 & 2,298 & 2,259 \\
From MoKaLO & To MO & 73,990 & 37,157 & 36,833 & & 6,139 & 3,260 & 2,875 \\
From Finland & To Baltic Sea & 1,633 & 887 & 746 & & 851 & 442 & 408 \\
From Finland & To Finland & 7,258 & 3,838 & 3,420 & & 5,221 & 2,666 & 2,555 \\
From Finland & To MO & 335 & 241 & 95 & & 711 & 477 & 233 \\
From MO & To Baltic Sea & 267 & 112 & 155 & & 271 & 106 & 166 \\
From MO & To Finland & 6,303 & 4,139 & 2,164 & & 1,564 & 841 & 722 \\
From MO & To MO & 6,747 & 4,408 & 2,338 & & 511 & 77 & 434 \\
\hline
\end{tabular}

According to the source-reception (SR) tables of EMEP status report 1/2013 the total Russian contribution to the Finnish $\mathrm{S}$ deposition in 2011 was $8.3 \mathrm{kt} \mathrm{S}$ and to the $\mathrm{NO}_{\mathrm{x}}$ deposition $14.3 \mathrm{kt} \mathrm{N}$, and to BS $4.6 \mathrm{kt} \mathrm{S}$ and $20.8 \mathrm{kt} \mathrm{N}$. The EMEP-calculated Finnish contributions to Finland were $10.6 \mathrm{kt} \mathrm{S}$ and $7.9 \mathrm{kt} \mathrm{N}$. The area used for Finnish area is smaller, but in the Hilatar model the lifetime of $\mathrm{S}$ compounds seems to be longer. Because the Russian source area is much smaller than in the EMEP SR tables in this study, the budgets between Finland and Russia cannot be directly compared.

In Lapland the high emissions from Kola industry are detected as high $\mathrm{SO}_{2}$ concentration peaks, however wet deposition is small because of low accumulated precipitation in general and especially during easterly winds, which are also rare in winter. Scavenging of $\mathrm{SO}_{2}$ with snow is also weak, and the humidity- and temperature-dependent conversion of $\mathrm{SO}_{2}$ to $\mathrm{SO}_{4}$ is slow especially in winter. The modelled dry deposition is rather high, as it should be: in Sevettijärvi, during the Lapland forest damage project, the measured S deposition was three times higher in forest than in open place (Tikkanen, 1995). Although the monthly variation of deposition from a single source area, especially when the target is not located downwind of the main wind direction, has high inter-annual variation due to large-scale weather changes and blocking, the role of dry deposition can be detected from high summertime deposition from Kola presented in Figure 2.

\section{Discussion}

In the old EMEP reports published in the 1990s, the $\mathrm{SO}_{2}$ emissions in Kola Peninsula were over $600 \mathrm{kt} \mathrm{SO}_{2}$ in 1990, the sulphur mass exchange budgets between Finland and Russia were realistic and the EMEP model estimated sulphur deposition in parts of Kola Peninsula exceeded $1.5 \mathrm{~g}(\mathrm{~S}) \mathrm{m}^{-2}$. Since 2004 the pollution budgets strongly underestimate the role of Russian emissions in Lapland. The purpose of international institutes is to highlight the main environmental problems for estimation of the pollution reductions needed. Thus it would be recommended to correct the emissions in EMEP inventory used in official country-to-country pollution SR budget calculations. 


\section{Acknowledgements}

I kindly acknowledge Dr. Curtis Wood for language corrections and comments.

\section{References}

Aardenne, J.A., Dentener, F.J., Olivier, J.G.J., Goldewijk, C.G.M.K. and Lelieveld, J. (2001) 'A $1^{\circ} \times 1^{\circ}$ resolution data set of historical trace gas emissions for the period 1890-1990', Global Biogeochemical Cycles, Vol. 15, No. 4, pp.909-928.

Bambulyak, A., Gulubeva, S. and Savinov, V. (2013) Assessment of the Barents Hot Spot Report, Part 1 - Analysis, Akvaplan-Niva Report NEFCO/BHSF, 119 pp.

CARMA (2014) Ummel, K. (2012) CARMA Revisited: an Updated Database of Carbon Dioxide Emissions from Power Plants Worldwide, CGD Working Paper 304, Center for Global Development, Washington DC, 30 pp. [online] http://www.carma.org/api (accessed 9 September 2015).

Efimov, A. (2007) Distributed Energy Production in the North-West Region of Russia, Master Thesis of Lappeenranta University of Technology, $220 \mathrm{pp}$.

Eurochem Annual Report (2014) Helping the World Grow, Annual Report and Accounts 2013, $136 \mathrm{pp}$. [online] http://www.eurochem.ru/wp-content/uploads/2014/04/EuroChem-AnnualReport-2013-ENG1.pdf.

FEI (2015) 'Air pollution emissions and statistics' [online] http://www.ymparisto.fi/enUS/Maps_and_statistics/Air_pollutant_emissions (accessed 9 September 2015).

Gerasimov, Y., Karvinen, S. and Leinonen, T. (2009) Atlas of the forest sector in Northwest Russia 2009, Working Papers of the Finnish Forest Research Institute, 43 pp.

Häkkinen, A.J., Markkanen, K., Hongisto, M., Kartastenpää, R., Milayaev, V.B., Yasensky, A., Kuznetsov, V.I., Kopp, I.Z. and Kivivasara, J. (1995) 'Emissions in St. Petersburg, the LO and Karelia', Proc. of the 10th World Clear Air Congress, Vol. 2, p.306.

Hansen, E. and Tønnessen, A. (1998) Environment and Living Conditions on the Kola Peninsula, Report 260, 265 pp, Fafo Institute of Applied Social Science, Falch Hurtigtrykk as, Norway.

Hongisto, M. (2003) Modelling of the Transport of Nitrogen and Sulphur Contaminants to the Baltic Sea Region, FMI Contributions No. 40, Helsinki, 188 pp.

Idän metsätieto (2010) [online] http://www.idanmetsatieto.info/fi/?ID=270\&newsGroup=1 (accessed 11 March 2010).

Jalkanen, J-P., Johansson, L., Kukkonen, J., Brink, A., Kalli, J. and Stipa, T. (2012) 'Extension of an assessment model of ship traffic exhaust emissions for particulate matter and carbon monoxide', Atmospheric Chemistry and Physics, Vol. 12, No. 5, pp.2641-2659.

Karelia (2014) Social and Economic Development of the Republic of Karelia in 2013 [online] http://www.gov.karelia.ru/gov/Info/2013/eco_resource13e_e.html (accessed 9 September 2015).

Karvosenoja, N. (2008) Emission Scenario Model for Regional Air Pollution, Monographs of the Boreal Environmental Research No. 32, Finnish Environmental Institute, 58 pp.

Knoema (2014) World Data Atlas Russian Federation [online] http://knoema.com/atlas/RussianFederation (accessed 9 September 2015).

Kozlov, M., Zvereva, E. and Zverev, V. (2009) Impacts of Point Polluters on Terrestial Biota. Comparative Analysis of 18 Contaminated Areas, 483pp, Springer Science \& Business Media, Dortrecht, Heidelberg, London, New York.

LO (2014) Leningrad Region [online] http://eng.lenobl.ru/ (accessed 9 September 2015).

Mäkelä, K. and Salo, M. (1993) Traffic Emissions in the Neighborough Areas of Finland, Vol. 199, 53pp, VTT Road-, Geo- and Traffic Laboratory Publication, Espoo. 
METLA (2014) Newsletters of the Finnish Forest Research Institute [online] http://www.metla.fi/uutiskirje/ (accessed 9 September 2015).

MO (1994) Review of the Air Polluting Emissions of the Murmansk Oblast (MO) in 1993. Committee of the Ecology and Natural Reserves of the MO, Ministry of Air Protection and Natural Reserves oft he Russian Federation, $16+70$ pp., in Russian.

MO (2014) Murmansk Regional Government Official Site [online] http://eng.gov-murman.ru/ (accessed 9 September 2015).

Mylona, S. (1996) 'Sulphur dioxide emissions in Europe 1880-1991 and their effect on sulphur concentrations and depositions', Tellus, Vol. 45B, No. 5, pp.662-689.

Norilsk Nikel (2015) Norilsk Nikel Annual Reports 1999-2014 [online] http://www.nornik.ru/en/investor-relations/annual-reports/annual-reports (accessed 9 September 2015).

NWPC (2014) North-Western Phosphorus Company AO [online] http://www.szfk.ru/en/ (accessed 9 September 2015).

Phosagro (2014) Statements and Reports [online] https://www.phosagro.com/investors/reports/ (accessed 9 September 2015).

RusAl (2014) Annual Reports 2009-2013 [online] http://www.rusal.ru/en/investors/reports.aspx (accessed 9 September 2015).

Segezha (2014) Segetsha Packaging [online] http://www.segezha-packaging.com/ (accessed 9 September 2015).

Severstal (2014) Severstal [online] http://www.severstal.com/eng/about/index.phtml; http://www.olcon.ru (accessed 9 September 2015).

Surgutneftegaz (2014) [online] http://www.surgutneftegas.ru/en/ecology/reports/ (accessed 9 September 2015).

Sveto (2014a) Svetogorsk Mill [online] http://www.ipaper.com/EMEA/EN/Company/Facilities/Svetogorsk.html (accessed 9 September 2015).

Sveto (2014b) Светогорск, Ленинградская область [online] http://www.sca.com/ru/russia/ (accessed 9 September 2015).

Syasky (2014) Syassky Pulp and Paper Mill [online] http://syas.ru/eng/ (accessed 9 September 2015).

TGC-1 (2014) TGC-1 Annual and Operational Reports [online] http://www.tgc1.ru/en/ir/reports (accessed 9 September 2015).

Tikkanen, E. (Ed.) (1995) The Kola Peninsula Pollution Stress for Forest in Lappland, Final Report of the East Lappland Forest Damage Project, 232 pp.

TNO (2007) MACC European Emission Inventory for the Years 2003-2007, TNO Report TNO-060-UT-2100-00588.

VTT (2015) Traffic Emission Calculation System [online] http://lipasto.vtt.fi/liisa/paastodata.htm (accessed 9 September 2015).

Wheeler, D. and Ummel, K. (2008) Calculating CARMA: Global Estimation of CO2 Emissions from the Power Sector, CGD WP 145. 